\title{
Development of Cassava Farming in Calcareous Land in Gunungkidul Regency Special Region of Yogyakarta
}

\author{
Eni Istiyanti \\ Departement of Agribusiness \\ Faculty of Agriculture Universitas \\ Muhammadiyah Yogyakarta \\ Yogyakarta \\ eniistiyanti@umy.ac.id
}

\author{
Nellysa Ayu V.C \\ Departement of Agribusiness \\ Faculty of Agriculture Universitas \\ Muhammadiyah Yogyakarta \\ Yogyakarta \\ nellysa.ayu.2014@fp.umy.ac.id
}

\author{
Lestari Rahayu \\ Departement of Agribusiness \\ Faculty of Agriculture Universitas \\ Muhammadiyah Yogyakarta \\ Yogyakarta \\ lestari@umy.ac.id
}

\begin{abstract}
The calcareous land is one of the alternative lands which are still underutilized in Gunungkidul Regency Special Region of Yogyakarta. This study aims to know and analyze the cost, income, profit, feasibility of the cassava farming, and the constraints towards developing cassava farming. The basic method used in this research is a quantitative and descriptive in nature. Respondents were chosen using simple random sampling and the total number of respondents is 60 farmers consisting of 30 calcareous land farmers and 30 farmers of rain fed land, both are active members of the farmers group. The results show that the total cost of cassava farming of rain fed land is higher than that in the calcareous land. However, the income and profit in cassava farming are higher in the calcareous land than that of rain-fed land. Overall, cassava farming in the rain-fed and calcareous land is feasible to develop. Furthermore, the study finds out that the farmers rain-fed lands are constrained by higher cost, but low prices of the products, while the farmers in the calcareous lands are challenged by the heavy rainfall, damaging the cassava plantation. This study recommends that the farmers should develop cassava production utilizing the calcareous land in Gunungkidul Regency.
\end{abstract}

Keywords-calcareous, cassava, development, rainfed

\section{INTRODUCTION}

Cassava is a strategic commodity as a source of income for the welfare of farmers in Indonesia. Cassava is the main food source after rice and corn which contains the energy of 146 $\mathrm{kcal} / 100$ grams of material [1]. Therefore, cassava has an important role in realizing national food security.

The main problems in realizing food security are changes in land use and population growth. The high rate of population growth and increasingly rapid development has resulted in many productive agricultural lands being transformed into the residential and industrial land. Data from the Directorate General of Facilities and Infrastructure of the Ministry of Agriculture in 2017 shows that the rate of conversion of productive agricultural land to non-productive is around 100,000 ha per year and $80 \%$ of them occur in Java.

Potential production of paddy fields or wetlands is greater than dry land, but the existence of paddy fields is much less than dry land, and thus, the alternative choice for cassava production of dry land is increasingly needed [2]. Dry land farming in various regions in Indonesia is quite profitable as Lampung Province can produce cassava of 43-50 tons/ha with a profit of 15-30 million rupiahs [3] and Bali Province with a productivity of 31.6 tons/ha of cassava can generate income of 31.6 million rupiah [4].

The most dominant land use for agriculture in Gunungkidul Regency is dry land in the form of rain-fed land and calcareous land. The calcareous land is one of the dry land areas that are widely spread in almost all regions of Gunungkidul [5]. The calcareous area has a hilly topography is mostly constituted of latosol or clay soil and has a minimum soil depth by an average of $<50 \mathrm{~cm} \mathrm{[6].} \mathrm{The} \mathrm{hilly} \mathrm{topography} \mathrm{of} \mathrm{calcareous} \mathrm{land}$ providing very little space for agricultural practices and is very vulnerable to the threat of soil erosion. One way to reduce the fast pace of erosion is by making terraces and planting intercropping [7].

There have been many studies addressing cassava farming in paddy fields or dry land, but no one concerns on cassava farming in calcareous land. The calcareous land is often taken by limestone to be used as building material. Therefore, the use of calcareous land for cassava farming requires special treatment that will affect production costs. There are many constraints that farmers will have to face in cassava cultivation in calcareous land. Hence, this study aims to determine the income and feasibility of cassava farming and to describe the constraints towards developing cassava farming in calcareous land in Gunungkidul Regency Special Region of Yogyakarta.

\section{METHODS}

This research uses the basic method of quantitative and descriptive analysis.

\section{A. Sampling Methods}

The research took place in Gunungkidul Regency, precisely in the Ponjong Sub-District. This area was chosen purposefully with given the consideration that $55 \%$ of the area was calcareous. Respondents were chosen using simple random sampling to determine the number of samples depending on the size of the sub-population or group representing it. It involved total number of 60 respondents of farmers consisting of 30 calcareous land farmers and 30 
farmers of rain-fed land, calcareous land farmers were taken from the Karsa Manunggal Farmers Association, while rainfed land farmers were taken from the Sahabat of the Farmers Association, both of which are active members of the farmers' group. The farmers grow cassava monoculture and intercropping pattern with pady and corn or peanut.

\section{B. Analysis Methods}

Income is the difference between total revenue and total explicit costs, while profit is the difference between total revenue and total costs [8]. Differences in income and profits between cassava farming in calcareous land and rain-fed land were analyzed using t test [9].

The feasibility of farming was analyzed by Revenue cost ratio $(\mathrm{R} / \mathrm{C})$, land productivity, labor productivity and capital productivity and cassava farming is said to be feasible if : $\mathrm{R} / \mathrm{C}$ $>1$, Land Productivity $>$ land rent, Labor Productivity $>$ labor wages and Capital Productivity $>$ interest [8]. The constraints of cassava farming development were analyzed descriptively.

\section{RESULTS AND DISCUSSION}

\section{A. Characteristics of Respondents}

$80 \%$ of Cassava farmers in calcareous and rain-fed land in Gunungkidul are less than 65 years old which means that they are still in productive age. In the productive age range, a person is in a prime physical condition and is responsive to every change or innovation [10]. A similar situation occurred among the cassava farmers in Southeast Ireland, which was dominated by young farmers of productive age [11].

Most cassava farmers in the calcareous and rain-fed land only completed the junior and senior high schools. This is in line with research conducted by [12], that the majority of cassava producers in Nigeria take junior high school education. The experience of cassava farming of rain-fed land farmers and calcareous land is more than 25 years. Farmers who have a longer farming experience tend to have more mature management capacity making them more cautious. Experience in agricultural cultivation, among others is seen from the farmers' ability to read microclimate, select cropping patterns and proper planting systems, and easy to accept innovation [13].

Cassava farmers in calcareous land and rain-fed land have the majority of land between 1,000-3,000 $\mathrm{m} 2$ classified in the smallholder category, namely farmers who carry out farming with a land of fewer than 0.5 hectares [14]. Most farmers use relatively narrow land by applying intercropping patterns between cassava with rice and cassava with corn or peanut. The intercropping planting pattern between cassava and peanuts aims to reduce soil erosion, especially in calcareous land. Soil erosion in the area of cassava planting can be prevented by planting a living fence on the edge of the land. Peanuts are better at reducing soil erosion than soybeans and green beans [15].

\section{B. Farming Analysis}

\section{1) Explicit Cost}

Respondents in this study were grouped based on the cropping patterns applied to each land. Cassava farmers with rain-fed land who applied intercropping patterns of rice-corn or peanut-cassava amounted to 17 people, intercropping corn or peanut-cassava amounted to 9 people, and those applying monoculture farming consisted of 4 farmers. Cassava farmers having calcareous land with intercropping planting patterns of rice-corn or peanut-cassava amountd to 26 people and intercropping of corn or peanut- cassava of 4 farmers.

Farming costs are the total costs incurred in the agriculture, consisting of explicit costs and implicit costs. Explicit costs are costs that are actually incurred by farmers in the form of production facilities costs, depreciation of equipment, labor outside the family, and other costs [8].

Table 1. Explicit costs of cassava farming in the rain-fed and calcareous land for 500 plants

\begin{tabular}{lrr}
\hline \multicolumn{1}{c}{ Explicit Cost } & Rain-fed Land & Calcareous Land \\
\hline Intercropping Rice-Corn & & Value (Rp) \\
or Peanut - Cassava & & \\
Production Fassilities & $\mathbf{4 0 7 , 2 2 5}$ & $\mathbf{3 6 9 , 2 1 2}$ \\
Depresiation Cost & 94,757 & 63,714 \\
Labor outside the family & 316,542 & 266,070 \\
Additional Cost & 59,324 & 104,467 \\
Total Explicit Cost & $\mathbf{8 7 7 , 8 4 8}$ & $\mathbf{8 0 3 , 4 6 3}$ \\
\hline Intercropping & & \\
Corn or Peanut-Cassava & & \\
Production Fassilities & 694,380 & 418,292 \\
Depresiation Cost & 159,715 & 62.572 \\
Labor outside the family & $\mathbf{7 8 2 , 6 3 9}$ & $\mathbf{5 5 2 , 6 5 6}$ \\
Additional Cost & 113,796 & 137,708 \\
Total Explicit Cost & $\mathbf{1 , 7 5 0 , 5 3 0}$ & $\mathbf{1 . 1 7 1 , 2 2 8}$ \\
\hline Monoculture & & \\
Production Fassilities & 326,804 & \\
Depresiation Cost & 104,649 & 0 \\
Labor outside the family & $\mathbf{4 1 7 , 4 4 4}$ & 0 \\
Additional Cost & 76,750 & 0 \\
Total Explicit Cost & $\mathbf{9 2 5 , 6 4 7}$ & $\mathbf{0}$ \\
\hline Aggregate & & $\mathbf{3 7 5 , 7 5 6}$ \\
Production Fassilities & $\mathbf{4 8 2 , 6 4 9}$ & \\
Depresiation Cost & 115,563 & \\
Labor outside the family & 469,825 & $\mathbf{8 5 2 , 5 0 0}$ \\
Additional Cost & 77,988 & \\
Total Explicit Cost & $\mathbf{1 , 1 6 , 0 2 5}$ & \\
\hline & & \\
\hline
\end{tabular}

In aggregate, the highest explicit costs are found at the cost of production facilities. Production facilities consist of seeds, organic fertilizers, chemical fertilizers, and pesticides. There are several seed varieties used by cassava farmers in Gunungkidul namely Gatotkoco, Ireng, Abang, Ketan, and Kirik. Rain-fed and calcareous land farmers mostly plant 2 types of varieties aiming to know the characteristics, yield potential, and to maintain local varieties. Gatotkoco varieties are widely used in rainfed land, while Ketan varieties, Kirik, and Abang have been cultivated on calcareous land.

The cost of manure is the biggest cost among the costs of other production facilities. In calcareous land, less manure is needed than rain-fed land. Manure in cassava farming is a basic fertilizer that is used when processing land. The use of manure and compost affects the availability of $\mathrm{N}, \mathrm{P}$, and $\mathrm{K}$ elements as a driver of plant growth. Manure can loosen the soil and facilitate the growth of cassava, especially during 
elongation. Spreading manure of 15 tons/ha will activate plant metabolism so that elongation and differentiation of cells will be better at increasing weight of fresh tubers [16].

In addition to using organic fertilizer, rain-fed land farmers and calcareous land use chemical fertilizer in the form of Urea fertilizer, Phonska. KCl, NPK, and TSP. The use of chemical fertilizers aims to meet nutrient requirements for and to increase the productivity of cassava plants. The majority of chemical fertilizers used by farmers are subsidies from the government that is channeled directly collectively from the Farmers Group to KUD in Ponjong Gunungkidul.

Most farmers use Urea and Phonska fertilizer because the price is relatively cheaper. Urea is needed by farmers. In addition, fertilizer in cassava plants is also used to accelerate the growth of cuttings. The treatment of dipping cuttings into the urea solution before planting could stimulate root growth and increase yield [14].

Other costs in cassava farming include taxes, vehicle rental, and fuel. The amount of tax is influenced by the location of the land whereon land near to highway the tax is Rp 30,000 per $1,000 \mathrm{~m}^{2}$ while the far land with the highway tax is $\operatorname{Rp} 20,000$ per $1,000 \mathrm{~m}^{2}$. Some farmers whose location are far from home, rent a car to transport their crops, while farmers living close to home simply use their own motorbike.

\section{2) Implicit Cost}

Implicit costs are costs that are not incurred in real terms but are still taken into account including labor in the family, own land rent and own capital interest [8].

Table 2. Implicit costs of cassava farming in the rain-fed and calcareous land for 500 plants

\begin{tabular}{lcc}
\hline & Rain-fed Land & Calcareous Land \\
\hline \multicolumn{1}{c}{ Implicit Cost } & Value (Rp) & Value (Rp) \\
\hline Intercropping: Rice-Corn & & \\
or Peanut-Cassava & & \\
Labor in Family & $\mathbf{5 9 7 , 9 6 2}$ & $\mathbf{4 1 5 , 3 4 8}$ \\
Own Land Rent & 106,271 & 124,575 \\
Own Interest Capital & 20,815 & 20,575 \\
Total Implicit Cost & $\mathbf{7 2 5 , 0 4 8}$ & $\mathbf{5 6 0 , 4 9 8}$ \\
\hline Intercropping Corn or Peanut- & & \\
Cassava & & $\mathbf{1 4 4 , 2 7 2}$ \\
Labor in Family & $\mathbf{3 3 5 , 0 9 7}$ & 112,917 \\
Own Land Rent & 128,356 & 28,910 \\
Own Interest Capital & 43,541 & $\mathbf{2 8 6 , 0 9 9}$ \\
Total Implicit Cost & $\mathbf{5 0 6 . 9 9 4}$ & $\mathbf{5 2 3 . 9 1 3}$ \\
\hline Monoculture & & 0 \\
Labor in Family & $\mathbf{2 3 6 , 3 2 9}$ & 0 \\
Own Land Rent & 56,429 & 0 \\
Own Interest Capital & 22,216 & 0 \\
Total Implicit Cost & $\mathbf{3 1 4 , 9 7 4}$ & \\
\hline Aggregate & & \\
Labor in Family & $\mathbf{4 7 0 , 8 8 4}$ & \\
Own Land Rent & & \\
Own Interest Capital & & \\
Total Implicit Cost & & \\
\hline & & \\
\hline
\end{tabular}

Cassava farming requires labor both from the family members and non-family members because the production process is quite heavy and requires a long time. The cost of using labor in the family on cassava farming is lower in calcareous land that of rain-fed land. Family labor is mostly used for post-harvest activities which include stripping cassava skin, and cutting cassava and drying, while labor costs outside the family are widely used for harvesting activities.

\section{3) Farm Income and Profit}

Table 3. Cassava farming income and profit in rain-fed and calcareous land in 500 plants

\begin{tabular}{ccr}
\hline \multirow{2}{*}{ Description } & Rain-fed Land & Calcareous Land \\
\cline { 2 - 3 } & Value (Rp) & Value (Rp) \\
\hline
\end{tabular}

Intercropping Rice-Corn or

Peanut-Cassava

\begin{tabular}{lrr} 
Revenue & $2,943,200$ & $2,971,554$ \\
Explicit Caost & 877,848 & 803,463 \\
Income & $\mathbf{2 . 0 6 5 . 3 5 2}$ & $\mathbf{2 . 1 6 8 . 0 9 1}$ \\
Implicit Cost & 725,048 & 560,498 \\
Profit & $\mathbf{1 , 3 4 0 , 3 0 4}$ & $\mathbf{1 , 6 0 7 , 5 9 3}$ \\
\hline
\end{tabular}

Intercropping Corn or Peanut-

\begin{tabular}{lrr} 
Cassava & & \\
Revenue & $3,191,398$ & $3,374,875$ \\
Explicit Caost & $1,750,530$ & $1,171,228$ \\
Income & $\mathbf{1 , 4 4 0 , 8 6 8}$ & $\mathbf{2 , 2 0 3 , 6 4 7}$ \\
Implicit Cost & 506,994 & 286,099 \\
Profit & $\mathbf{9 3 3 , 8 7 4}$ & 0 \\
\hline Monoculture & & $\mathbf{1 , 9 1 7 , 5 4 8}$ \\
Revenue & $3,164,910$ & 0 \\
Explicit Caost & 925,647 & 0 \\
Income & $\mathbf{2 . 2 3 9 . 2 6 3}$ & 0 \\
Implicit Cost & 314,974 & \\
Profit & $\mathbf{1 , 9 2 4 , 2 8 9}$ & \\
\hline Aggregate & & $\mathbf{8 5 2 , 5 0 0}$ \\
Revenue & $3,047,346$ & $\mathbf{2 , 1 7 1 , 0 6 0}$ \\
Explicit Caost & $1,146,025$ & 523,913 \\
Income & $\mathbf{1 , 9 0 1 , 3 2 1}$ & $\mathbf{1 , 6 4 7 , 1 4 7}$ \\
Implicit Cost & 604,955 & \\
Profit & $\mathbf{1 , 2 9 6 , 3 6 6}$ & \\
\hline & & \\
\hline
\end{tabular}

The production that is sold by cassava farmers in Gunungkidul is in the form of Gaplek so that it can be stored for a longer time. Processing cassava into Gaplek can reduce moisture content by $13-15 \%$ and the decrease in moisture content is influenced by the time and temperature of drying [17]. Cassava farming acceptance for 500 plants on calcareous land is relatively the same as rain-fed land. This is because the production of various cropping patterns chosen by rain-fed farmers and calcareous land is almost the same, ranging from $2,080-2,375 \mathrm{~kg}$ with a price range of $\mathrm{Rp} 1,400-1,425 \mathrm{per} \mathrm{kg}$.

Cassava farming income of calcareous land in various cropping patterns is greater than that in rain-fed land. The resulted income is determined by production, selling prices and production costs. This is consistent with the research of [18] and [4]. Based on the t-test, it is obvious that there is no 
difference between the cassava farming income and profit of calcareous land and rain-fed land in Gunungkidul Regency.

\section{4) Feasibility Farming}

Table 4. Feasibility of cassava farming in rain-fed and calcareous land for 500 plants

\begin{tabular}{|c|c|c|}
\hline \multirow{2}{*}{ Description } & Rain-fed Land & Calcareous Land \\
\hline & Value & Value \\
\hline \multicolumn{3}{|l|}{$\begin{array}{l}\text { Intercropping Rice- Corn or } \\
\text { Peanut-Cassava }\end{array}$} \\
\hline Land Productivity $\left(\mathrm{Rp} / \mathrm{m}^{2}\right)$ & 546 & 591 \\
\hline Labor Productivity (Rp/wd) & 163,291 & 242,850 \\
\hline Capital Productivity (\%) & 155 & 203 \\
\hline $\mathrm{R} / \mathrm{C}$ & 1.84 & 2.18 \\
\hline \multicolumn{3}{|l|}{$\begin{array}{l}\text { Intercropping Corn or Peanut- } \\
\text { Cassava }\end{array}$} \\
\hline Land Productivity $\left(\mathrm{Rp} / \mathrm{m}^{2}\right)$ & 340 & 744 \\
\hline Labor Productivity (Rp/wd) & 202,388 & 701,299 \\
\hline Capital Productivity (\%) & 56 & 166 \\
\hline $\mathrm{R} / \mathrm{C}$ & 1.41 & 2.32 \\
\hline \multicolumn{3}{|l|}{ Monoculture } \\
\hline Labor Productivity (Rp/wd) & 479,073 & 0 \\
\hline Capital Productivity (\%) & 210 & 0 \\
\hline $\mathrm{R} / \mathrm{C}$ & 2.55 & 0 \\
\hline \multicolumn{3}{|l|}{ Aggregate } \\
\hline Land Productivity $\left(\mathrm{Rp} / \mathrm{m}^{2}\right)$ & 534 & 610 \\
\hline Labor Productivity (Rp/wd) & 191,059 & 262,848 \\
\hline Capital Productivity (\%) & 116 & 196 \\
\hline $\mathrm{R} / \mathrm{C}$ & 1.74 & 2.19 \\
\hline
\end{tabular}

Information: wd = work day

Based on the analysis of the $\mathrm{R} / \mathrm{C}$ (revenue cost ratio), it comes to light that cassava farming on calcareous land and on rain-fed land is feasible because of $\mathrm{R} / \mathrm{C}>1$. The highest $\mathrm{R} / \mathrm{C}$ value of cassava farming in the rain-fed land is found in the monoculture cropping pattern, while the intercropping pattern of corn or peanut- cassava on calcareous land has the largest $\mathrm{R} / \mathrm{C}$ value. The results are in line with the research conducted by [19] that cassava intercropped with corn can increase the value of $\mathrm{R} / \mathrm{C}$.

Feasibility analysis based on land productivity criteria shows that cassava farming in calcareous land and rain-fed land is feasible to cultivate. Hence, it is better to use calcareous land and rain-fed land for cassava farming than for leasing. Overall, the productivity of cassava farming land in calcareous land is higher than that in rain-fed land. The cropping pattern of intercropping of corn or peanut - cassava on calcareous land has the highest land productivity, meaning that with a certain land area this cropping pattern is able to produce higher income than other cropping patterns.

Based on the feasibility analysis seen from labor productivity, cassava farming in calcareous land and rain-fed land is feasible because the labor productivity is greater than the labor wage that applies in Gunungkidul. This is in line with research conducted by [20], that the productivity of cassava farming labor in Wanurojo Village is greater than the prevailing labor wage rate.

Overall, the productivity of cassava farming in the calcareous land is higher than that in rain-fed land. Therefore, it is better to use the farmers' capital for cassava farming than to be saved. This situation is similar to the research conducted by [20], revealing that the productivity of cassava farming capital is greater than the interest of the BRI Bank of Kemiri unit, Purworejo Regency.

\section{Constraints of Cassava Farming}

Cassava farmers in Gunungkidul Regency have to face various constraints in farming. The biggest constraint facing cassava farmers in the calcareous land is the high rainfall. Cassava farming is generally carried out at the beginning of the rainy season because for irrigation, the farmers can only rely on rainfall. However, cassava plants that get too much water will be susceptible to diseases leading them to death. According to [21], cassava is a plant that requires relatively little water around $40 \mathrm{~mm} / 10$ days for the first month, 50-60 $\mathrm{mm} / 10$ days at 2-3 months, $65-75 \mathrm{~mm} / 10$ days from age 4 months to 1 month before harvest, and $50 \mathrm{~mm} / 10$ days at harvest. If the water conditions are stagnant 8 hours/day continuously for 7 days, cassava will die because the cassava root is not resistant to anaerobic conditions such as rice roots.

Table 5. Constraints of cassava farming in calcareous and rainfed land

\begin{tabular}{lcccc}
\hline \multirow{2}{*}{ Constrains } & \multicolumn{2}{c}{$\begin{array}{c}\text { Farmer of rain-fed } \\
\text { land }\end{array}$} & \multicolumn{2}{c}{$\begin{array}{c}\text { Farmer of calcareous } \\
\text { land }\end{array}$} \\
\cline { 2 - 6 } & $\begin{array}{l}\text { Amount } \\
\text { (person) }\end{array}$ & $\begin{array}{l}\text { Percentage } \\
\text { (\%) }\end{array}$ & $\begin{array}{c}\text { Amount } \\
\text { (person) }\end{array}$ & $\begin{array}{c}\text { Percentage } \\
\text { (\%) }\end{array}$ \\
\hline $\begin{array}{l}\text { Cost of Expensive } \\
\begin{array}{l}\text { Pesticides } \\
\text { Land processing is }\end{array}\end{array}$ & 0 & 0 & 1 & 3.33 \\
difficult & 1 & 3.33 & 4 & 13.33 \\
$\begin{array}{l}\text { Rainfall is high so } \\
\text { plant easy die }\end{array}$ & 10 & 33.33 & 15 & $\mathbf{5 0 . 0 0}$ \\
$\begin{array}{l}\text { Long harvest time } \\
\text { Low cassava prices }\end{array}$ & 2 & 6.67 & 2 & 6.67 \\
$\begin{array}{l}\text { Hard transport } \\
\begin{array}{l}\text { Competition } \\
\text { between tall plants }\end{array}\end{array}$ & 12 & $\mathbf{4 0 . 0 0}$ & 9 & 30.00 \\
$\begin{array}{l}\text { Availability of old } \\
\text { subsidized }\end{array}$ & 1 & 6.67 & 2 & 6.67 \\
$\begin{array}{l}\text { There are no } \\
\text { constraint }\end{array}$ & 2 & 3.33 & 0 & 0 \\
\hline
\end{tabular}

The highest constraint felt by cassava farmers is rain-fed land which is low leading to fluctuating cassava prices. If the harvest is high, cassava production is abundant so the price of cassava becomes very low. This is because there is no evenly planned planting and harvest time between regions. The majority of rain-fed and calcareous land farmers grow cassava in the rainy season so that water needs are met [22].

The farmers on calcareous and rain-fed land find it difficult to process land. Land processing by calcareous farmers is still manually conducted using human labor because the tractor cannot reach the land. Managing land on the land manually requires a lot of labor and a long time so that it will increase labor costs. Transportation constraints that are difficult to be felt 
by farmers in the calcareous and rain-fed land. Some farmers have land that is far from home. Road access to calcareous land is almost entirely rocky, uphill and narrow, making it difficult for farmers to transport production facilities (seeds, fertilizers, pesticides) to the land. This has the effect on delaying the application of fertilizers and causing nutrient-deficient plants needed during the growth process. Delay in fertilization also affects cassava to be small or dwarf, thus reducing crop productivity. In line with the research conducted by [23], that fertilizer is a vital thing so that the availability of cheap and apply easy fertilizer will facilitate the cultivation process.

\section{CONCLUSION}

Calcareous land farmers in Gunungkidul only apply intercropping patterns between cassava and rice, corn or peanut, while rain-fed cassava farmers use monoculture and intercropping. The cost of farming cassava on calcareous land at various cropping patterns is lower than that of rain-fed land, so the income and profits are higher. Cassava farming in calcareous and rain-fed land in Gunungkidul Regency is feasible to be developed in terms of $\mathrm{R} / \mathrm{C}$, land productivity, labor productivity and capital productivity.

Cassava farmers consider that the biggest constraint in cassava cultivation is high rainfall, which can cause death in cassava plants. Meanwhile rain-fed farmers consider that the main constraint in cassava farming is the low and fluctuating price. Cassava farmers in Gunungkidul need assistance in determining the right planting time in order to minimize the risk of death in plants. The Agriculture Office needs to regulate crop rotation in each district to avoid simultaneous harvest so that farmers get a higher selling price.

\section{ACKNOWLEDGMENT}

The research presented in this paper was part of a research grant under the Unggulan Program Studi research schemes and thank you to LP3M Universitas Muhammadiyah Yogyakarta for facilitating funding for this research.

\section{REFERENCES}

[1] Suwarto, S. Yahya, Handoko, and M.A. Chozin, "Kompetisi Tanaman Jagung dan Ubi Kayu dalam Sistem Tumpangsari," Buletin Agron. Vol. 33 No. 2, pp: 1-7, 2005

[2] F. Nuraini, and H. Pramono, "Kajian Karakteristik dan Potensi Kawasan Karst untuk Pengembangan Ekowisata di Kecamatan Ponjong Kabupaten Gunungkidul", Geomedia: J. Vol.11 No. 1 pp : 109-127, 2014

[3] B.S. Radjit, Y. Widodo, N. Saleh, and N. Prasetiaswati, "Teknologi untuk Meningkatkan Produktivitas dan Keuntungan Usahatani Ub Kayu di lahan Kering Ultisol”, Iptek Tanaman Pangan: Buletin, Vol. 9 No.1 pp: 51-62, 2014

[4] I.N. Mardika, I.K. Rantau, and P.U. Wijayanti, 2017. "Analisis Usahatani Ubi Kayu Varietas gajah Studi Kasus di Kelompok TaniTernak Kerti Winangun, Desa Bukti, Kecamatan Kabutambahan, Kabupaten Buleleng”, Agri dan Agro J. Vol. 6 No. 2. Pp: 231-239, 2017

[5] D.N. Tyas, R.Vitdiawati, and R. Nusantari, "Konservasi dan Pemanfaatan Berkelanjutan Kawasan Karst Gunung Sewu sebagai Bagian Geopark untuk Mempertahankan Funfsi Ekologi." Symbion (Symposium on Biology Education): Proceeding, Departement of Biology Universitas Ahmad Dahlan, 2016

[6] R.D. Rahmi, K.Suratiyah, and J.H. Mulyo, "Ketahanan Pangan Rumah Tangga Petani di Kecamatan Ponjong Kabupaten Gunungkidul”, Agro Eko :J. Vol. 24 No. 2 pp:190-210, 2013
[7] P.S. Dyah, "Manajemen Usahatani pada Lahan Kering di Kabupaten Gunung Kidul Daerah Istimewa Yogyakarta", Interdisciplinary Postgraduate Student Conference 3rd : Proceeding, Universitas Muhammadiyah Yogyakarta, pp: 274-278, 2016

[8] K. Suratiyah, "Ilmu Usahatani", Penebar Swadaya Press, Jakarta, 2006

[9] Suliyanto, "Ekonometrika Terapan : Teori dan Aplikasi dengan SPSS", Andi Press, Yogyakarta, 2011

[10] A.Charina, R.A.B. Kusumo, A.H. Sadeli, and D. Deliana, "Faktorfaktor yang Mempengaruhi petani dalam Menerapkan Standar Operasional Prosedur (SOP) Sistem Pertanian Organik di Kabupaten Bandung Barat", Penyuluhan: J, Vol 14.No.1 pp:68-78, 2018

[11] U.C. Ibekwe, J.S. Orebiyi, H.A. Ukoha, E.C.Okorji, E.C. Nwagbo, and C.M.N. Mark," Resource Use Efficiency in Cassava Production in South East Nigeria", Asian J. Agri Ext, Eco \& Soc, Vol 1. No. 1 pp:1621,2012

[12] N.S. Chimela, A.C. Monica, A.C, A.A. Jacob, and O.K. Nkem, O.K "Impact of Returns from Cassava Production and Processing on Poverty among Women in Abia State, Nigeria”, Asian J. Agri Ext, Eco \& Soc Vol. 13 No. 4 pp:1-10, 2016

[13] A.N. Setiawan, B.H. Isnawan, and L.N. Aini, "Sistem Pengelolaan Lahan Pasir Pantai untuk Pengembangan Pertanian”, unpublished

[14] S.H. Susilowati, and M. Maulana, "Luas Lahan Usahatani dan Kesejahteraan Petani: Eksistensi Petani Gurem dan Urgensi Kebijakan Reforma Agraria", Analisis Kebijakan Pertanian: J Vol 10 No.1 pp: 17-30, 2012

[15] Subandi, "Teknologi Budidaya Tumpangsari Ubi Kayu-Kacang Tanah Mendukung Sistem Integrasi Ternak-Tanaman pada Lahan Kering Masam”, Buletin Palawija: No. 19. pp:1-13, 2010

[16] F. Azizah, A.Sulistyo, and Subagiya, "Pertumbuhan dan Hasil Ubi Jalar dengan Pemberian Pupuk Kandang serta Uji Varietas terhadap Cylas Formicalius", Agro Res :J. Vol 2. No 1. pp 22-27, 2018

[17] M. Purwanti, P. Jamaluddin, and Kadirman, "Penguapan Air dan Penyusutan Irisan Ubi Kayu Selama Proses Pengeringan Menggunakan Mesin Cabinet Dryer", Pendidikan Teknologi Pertanian : J. Vol 3 No.2 pp: 127-136, 2017

[18] M. Thamrin, A. Mardhiyah, and S.E. Marpaung, "Analisis Usahatani Ubi kayu (Manihot utilissima)", Agri: J. Vol 18, No 1. pp: 57-64, 2013

[19] H.D. Nugraha, A. Suryanto, and A. Nugroho, "Kajian Potensi Produktivitas Ubikayu (Manihot Esculenta Crant.) di Kabupaten Pati. Produksi Tanaman: J. Vol. 3 No. 8 pp: 673-682, 2015

[20] P. Nahari, and Zulfanita, "Efisiensi Penggunaan Faktor-faktor Produksi Usahatani Ubi Kayu di daerah Pegunungan Desa Wanurojo, Kecamatan Kemiri, Kabupaten Purworejo”, Surya Agritam:a J. Vol. 6 No.1. pp:82-91, 2017

[21] J. Wargiono, Kartika, and Solihin, "Areal Pertanaman dan Sistem Produksi Kebijakan Teknis Pengembangan dan Inovasi Teknologi”, Bogor, 2014

[22] H. Sukesi, "Kajian Rantai Pasokan dan Penganekaragaman Konsumsi Pangan Berbasis Produk Umbi-umbian (Studi Kasus Jawa Barat)" Buletin Ilmiah Litbang Perdagangan:Vol 4 No.1 pp: 31-62, 2016

[23] B.Y.Ariadi, M.Haeruman, D. Rochdiani, and E. Rasmikayati, "Model Dinamik Manajemen Ubi Kayu", AGRARIS: J. Agri. Rur. Dev.Res. Vol. 1 No. 1.pp:32-40, 2015 